\title{
Correction to: Globally regional life cycle analysis of automotive lithium-ion nickel manganese cobalt batteries
}

\author{
Jarod C. Kelly ${ }^{1}$ (D) Q Qiang Dai ${ }^{1} \cdot$ Michael Wang ${ }^{1}$
}

Published online: 29 May 2020

(C) The Author(s) 2020

\section{Correction to: Mitig Adapt Strateg Glob Change https://doi.org/10.1007/s11027-019-09869-2}

The article Globally regional life cycle analysis of automotive lithium-ion nickel manganese cobalt batteries written by Jarod C. Kelly, Qiang Dai and Michael Wang, was originally published electronically on the publisher's internet portal (currently SpringerLink) on August 28, 2019, without open access. With the author(s)' decision to opt for Open Choice the copyright of the article changed on May 2020 to (C) The Author(s) 2020 and the article is forthwith distributed under the terms of the Creative Commons Attribution 4.0 International License (http://creativecommons.org/licenses/by/4.0/), which permits use, duplication, adaptation, distribution and reproduction in any medium or format, as long as you give appropriate credit original author(s) and the source, provide a link to the Creative Commons license and indicate if changes were made.

Open Access This article is licensed under a Creative Commons Attribution 4.0 International License, which permits use, sharing, adaptation, distribution and reproduction in any medium or format, as long as you give appropriate credit to the original author(s) and the source, provide a link to the Creative Commons licence, and indicate if changes were made. The images or other third party material in this article are included in the article's Creative Commons licence, unless indicated otherwise in a credit line to the material. If material is not included in the article's Creative Commons licence and your intended use is not permitted by statutory regulation or exceeds the permitted use, you will need to obtain permission directly from the copyright holder. To view a copy of this licence, visit http://creativecommons.org/licenses/by/4.0/.

Publisher's note Springer Nature remains neutral with regard to jurisdictional claims in published maps and institutional affiliations.

The online version of the original article can be found at https://doi.org/10.1007/s11027-019-09869-2

Jarod C. Kelly

jckelly@anl.gov

1 Argonne National Laboratory, 9700 South Cass Avenue, Lemont, IL 60439, USA 